小山 靖人*・瀬尾 明繁・高田 十志和

\title{
Polymer Modification Exploiting Stable Nitrile $N$-Oxide
}

Yasuhito KOYAMA*, Akishige SEO, Toshikazu TAKATA (Department of Organic and Polymeric Materials, Tokyo Institute of Technology, 2-12-1 (H-126), Ookayama, Meguro-ku, Tokyo 152-8552, Japan)

This paper describes the powerful practical modification method of elastomers with unsaturated bonds exploiting kinetically stabilized nitrile $N$-oxides. The stable nitrile $N$-oxides enable the efficient 1,3-dipolar cycloaddition to both internal olefin and nitrile groups incorporating into versatile elastomers such as acrylonitrile butadiene rubber (NBR), natural rubber (NR), and ethylene-propylene-diene terpolymer (EPDM) to give the corresponding hetero aromaticscontaining polymers. The reaction features i) catalyst-free procedure, ii) versatile applicability to various elastomers, iii) high yield, iv) high regio-selectivity, v) no by-product, and vi) remarkable acceleration of reaction rate under solvent-free condition. The scope and limitation of the modification reaction are discussed in detail.

(Received on September 2, 2010)

(Accepted on January 8, 2011)

Key Words : Stable Nitrile N-Oxide, Click Reaction, Elastomer, Polymer Modification, Catalyst-free Reaction

\section{1. 緒言}

多彩な物性を兼ね備えたエラストマーを自在に合成する ことは非常に難しい．全ての要求を満足するようなモノマ 一を新規に設計し，精密に重合すれば，確かに望みの性質 を持つエラストマーが得られると期待できるものの，この 方法では莫大なコストと時間が必要とされる。その反面, 十分に物性が分かっているエラストマーに対し，高分子反 応による修飾反応を利用すれば，その反応率に応じて物性 を精密にチューニングすることができる点で，より有用な 方法であると言える ${ }^{1)}$. さらに理想を言えば，その高分子 反応があらゆるエラストマーに万能的に使用可能であり, 無触媒・無溶媒で進行し, 副生成物を伴わないような反応 であれば，新しいエラストマーの創成において極めて実用 的であると考えられるものの，現状ではそのような反応は ほとんど知られていない. エラストマーの化学修飾に関す る研究は, 架橋を意図した研究に比べると比較的少なく, 多くの研究の余地を残している.

そこで本研究では多様な不飽和結合からなるポリマーに対 し，i）沉用性が高く，ii）触媒の必要が無く， iii）副生成物も 生成しないような付加反応を実現可能なニトリルオキシドの 利用に着目した ${ }^{2,3)}$ ニニトリルオキシドは炭素-窒素酸素から

*東京工業大学大学院理工学研究科

（１52-8552＼cjkstart東京都目黒区大岡山2-12-1 H-126）
なるアレン型の 1,3-双極子であり, 無触媒でアルケン, アル キン，ニトリルなどの多様な不飽和結合と反応することが知 られており ${ }^{4)}$ エラストマーの高分子修飾反応として極めて 魅力的な官能基である (Figure 1). しかしながら, 通常ニト リルオキシドは不安定であり， 2 量化反応が容易に起こって フロキサンへと変換されることが知られている5). また，二 トリルオキシド単独の分解反応として, 熱的, 光化学的条件 下においてイソシアナートへの転位反応も知られている (Figure 2) ${ }^{6,7)}$ ・こうした欠点のため，ニトリルオキシドを用 いた修飾反応は取り扱いに細心の注意が必要であり, ポリマ 一合成への応用が困難であると考えられてきたため, その報 告例は数例に留まっている ${ }^{8-13)}$. 最近報告された高分子修飾 反応における成功例としては, 反応性の高い未端アセチレン や14), 立体的に歪んだ活性なオレフィンであるノルボルネン 骨格を予め組み込んだポリマーを合成しておくことが前提で

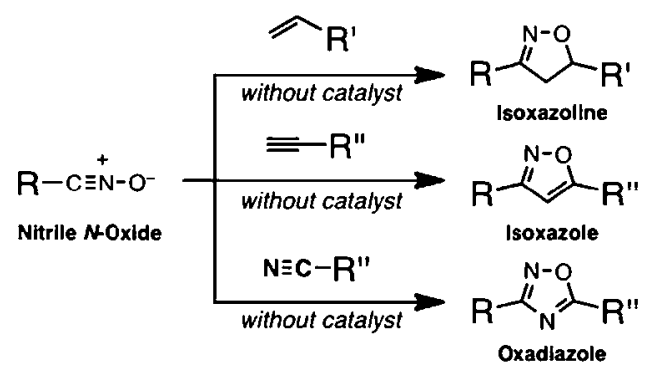

Figure 1 1,3-Dipolar cycloaddition of nitrile $N$-oxide with various unsaturated bonds. 


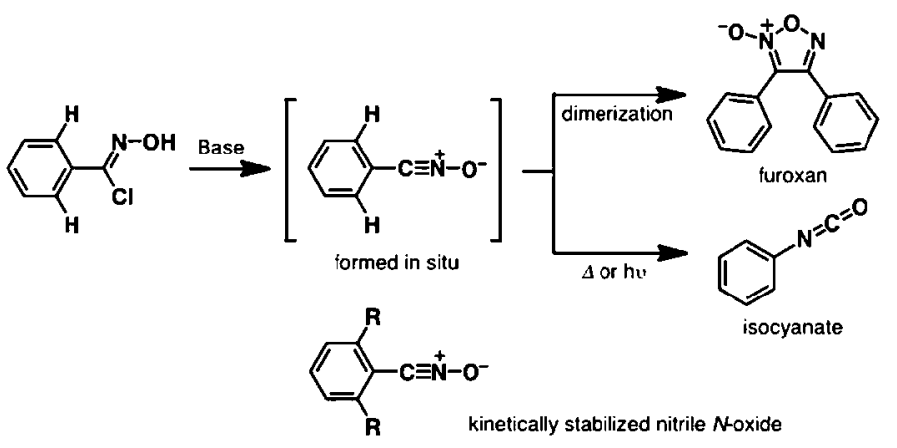

Figure 2 Decomposition pathways of aromatic nitrile $N$-oxide and kinetically stabilized aromatic one.

あり ${ }^{15)}$ ，そのポリマーに対して過剩量のヒドロキサモイルク ロリドと塩基を加えることで，系内でニトリルオキシドを発 生させ，その高分子反応によって反応活性な不飽和結合部位 を修飾するというものである：しかしながら，この方法論で は基質となるポリマーの一般性は低く，塩基が添加剤として 必要であり，副生成物として塩酸も生じるため，沉用エラス トマーへの応用展開は困難であると言っても過言ではない.

こうした問題を克服すべく，筆者らは速度論的に安定化 されたニトリルオキシドを用いることを計画した ${ }^{16,17)}$ 。十 分に高高い置換基が隣接する時，ニトリルオキシドは安定 に単離することが可能である. 特に芳香族ニトリルオキシ ドの場合は，その両オルト位に適当な置換基を導入するだ けで，効果的に 2 量化反応が抑制され，加熱条件下でも安 定に存在でき，耐水性も著しく向上する。そこで筆者らは， この安定ニトリルオキシドを利用すれば，無触媒条件下で の付加反応が可能になるだけでなく, 従来までは反応不活 性であった汎用エラストマー中のニトリル基や内部オレフ インの修飾も可能になると想定した。

そこで本研究では速度論的に安定化されたニトリルオキ シドを利用し，汎用エラストマーの修飾反応について検討 したので詳細を報告する。

\section{2. 実}

験

\section{1 試薬および供試ゴム}

原料ゴムにはアクリロニトリル-ブタジエンゴム（NBR, 結合アクリロニトリル量 $=33 \%$, 日本ゼオン株式会社, DN-3380)，エチリデンノルボルネン (ENB) 系エチレンプロピレン-ジエン三元共重合体（EPDM（ENB)，結合 $\mathrm{ENB}$ 量 $=10 \%$, JSR 株式会社, EP-331），および天然ゴム (NR, Taiko Plantations Sdn. Bhd., SMR CV60) を, 溶媒にはクロロホルム（信越化学株式会社）およびメタノ ール（関東化学株式会社）を，反応剤には水酸化ナトリウ ム (ナカライテスク株式会社), ヒドロキシルアミン塩酸 塩および臭素（和光純薬株式会社）を市販品のまま使用し た。

\section{2 測定}

${ }^{1} \mathrm{H}$ NMR 測定はJEOL 社製 AL-400（400 MHz）の装置 を用い，溶媒には重クロロホルムを使用した。なお，内部 標準物質としてはテトラメチルシランを用いた。IR測定 には日本分光社製JASCO FT/IR-230を用い，KBrを利用 して測定した。融点測定にはStuart Scientific社製 MELTING POINT APPARATUS SMP3を用いた.

\section{3 安定ニトリルオキシドの調製}

安定ニトリルオキシドは文献の手法を若干改良し，それ

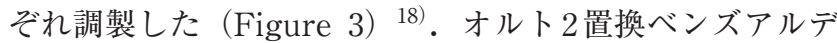
ヒドである 2,6 -ジメトキシベンズアルデヒドに対し，ヒド ロキシルアミンを作用させるとオキシムが沈殿として得ら れた。このオキシムを沪取後, クロロホルムー水酸化ナト リウム水溶液の混合溶媒中で臭素をゆっくりと滴下する と，目的とするニトリルオキシドII を高収率且つ高純度 で得られることが明らかとなった。このニトリルオキシド II はクロロホルムーヘキサン混合溶媒中で再結晶し, 132.1 - $132.7{ }^{\circ} \mathrm{C}$ 融点幅を示す無色の板状結晶として単離さ

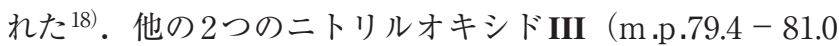
$\left.{ }^{\circ} \mathrm{C}\right)$, IV (m.p.100.8 - $102.3{ }^{\circ} \mathrm{C}$ ) ${ }^{16)}$ も同様の手法で合成し, それぞれ結晶として得られた。得られた結晶はいずれも冷 蔵庫中で数ヶ月の保存が可能であった。

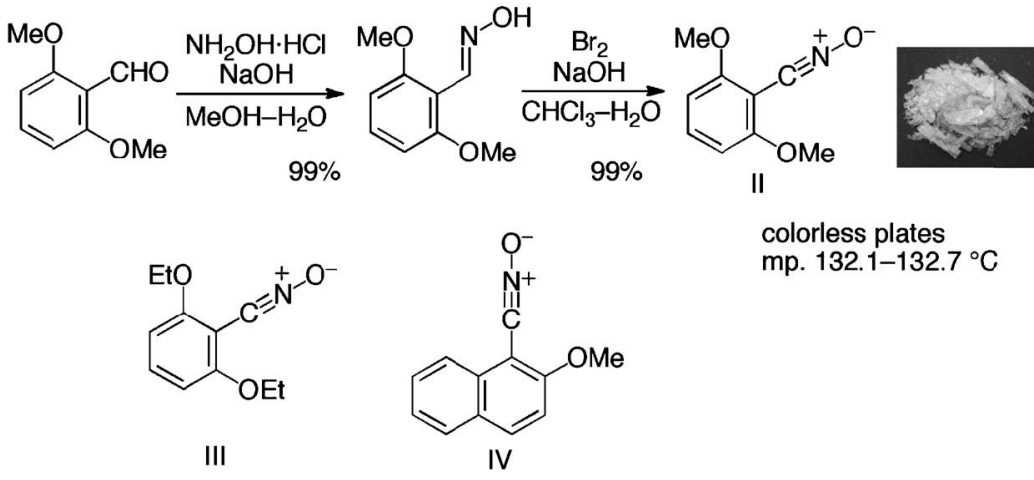

Figure 3 Preparation of stable nitrile $N$-oxide. 


\section{4 ニトリルオキシドを用いた高分子修飾反応}

エラストマーに対する安定ニトリルオキシドの付加反応 は以下に示すような手順で行った。

クロロホルムに溶解させたエラストマーに対し, 安定ニ トリルオキシドを室温で加えた後に, 昇温して還流させ, 所定の時間かくはんした。その後室温まで泠却し，メ夕ノ ール中に反応溶液を滴下することで再沈殿し, 白色沈殿を 得た。減圧沪過して沈殿を回収し，一晚真空乾燥し，修飾 エラストマーを得た。 ${ }^{1} \mathrm{H}$ NMR 測定によって, 安定ニトリ ルオキシドのピークが無いことを確認後, 積分比から修飾 率（conv.）を算出した。また修飾率に相当する理論収量 を求め，そこから収率（yield）を算出した。

\section{3. 結果および考察}

\section{1 対照実験}

まず，既法であるヒドロキサモイルクロリドに塩基を作 用させて，系内でニトリルオキシドI（不安定ニトリルオ キシド）を発生させる方法を用いて付加反応を検討した. エラストマーとしては，内部オレフィン及びニトリル基を 併せ持つNBRを用いた。 クロロホルムにNBRを溶解させ， ヒドロキサモイルクロリドを加えた後, 塩基であるトリエ チルアミンを室温でゆっくりと滴下した。その後，還流さ せて 2 日間反応を行った（Figure 4). 室温に冷却後，メ タノールに再沈殿させてポリマーを回収し，付加率を求め るため ${ }^{1} \mathrm{H}$ NMR 測定を行った所，ほとんど付加反応は進 行していないことが明らかとなり，原料のNBRが定量的 に回収されたことが分かった。

この付加反応が進行しなかった理由は，ニトリル基や内 部オレフィンとの付加反応には高い活性化エネルギーが必 要であるものの，用いたニトリルオキシドが不安定で，加
熱条件下で分解してしまったためであると考察した。

\section{2 モデル反応}

安定ニトリルオキシドを用いたポリマーへの付加反応を 検討する前に，低分子での 1,3-双極子付加反応における反 応性，位置選択性について検討した，様々なエラストマー や繊維，樹脂などに利用されるアクリロニトリル共重合体 への修飾反応を期待し, そのモデル分子としてアセトニト リルを，また天然ゴムのような内部オレフィンを有するポ リマーへの修飾反応を期待して2-メチル-2-ブテンをそのモ デル分子として用い，安定ニトリルオキシドIIを用いて 付加反応を検討した（Figure 5)。その結果，いずれも室 温付近では全く反応しないものの, 加熱条件下で反応し, 対応する付加体がそれぞれ定量的に得られることが明らか となった。得られた生成物について, HMBC及びNOESY 測定を行った結果，Figure 5 に示すようなそれぞれ単一の 位置異性体であることが分かった。この高い位置選択性は ニトリルオキシドの両オルト位の置換基に由来する立体的 要因により, 環化時の立体障害が小さくなるような位置で 付加したためであると考えられる。

\subsection{NBRの修飾反応}

上述のモデル反応で得た知見を利用し，モデル反応とほ ぼ同様の条件下でNBRの修飾反応について検討した (Figure 6).

まず安定ニトリルオキシドIIを用いて付加反応を検討 した。NBRをクロロホルムに溶解し，不飽和結合に対し て 1.2 当量のニトリルオキシドを混合し，還流した。尚， 溶媒量は全ての検討を通し，ニトリルオキシドの濃度が $1.0 \mathrm{M}$ になるように統一した。 2 時間還流後にメ夕ノール に反応液を投入することで反応を停止し，得られた沈殿 を沪過，乾燥し，修飾 NBRを得た。また，ニトリル基と

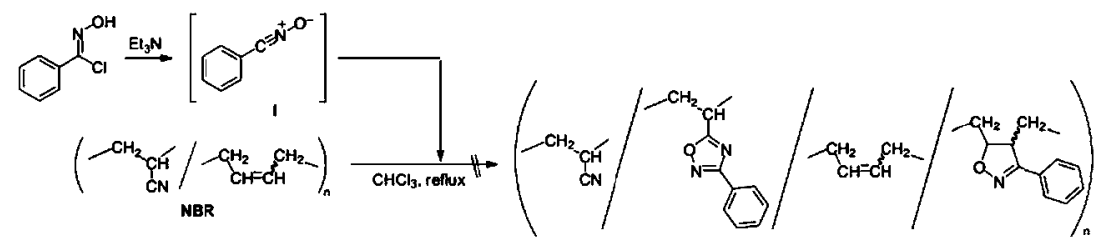

Figure 4 Attempted modification of NBR using nitrile $N$-oxide I generated in situ from hydroxamoyl chloride.

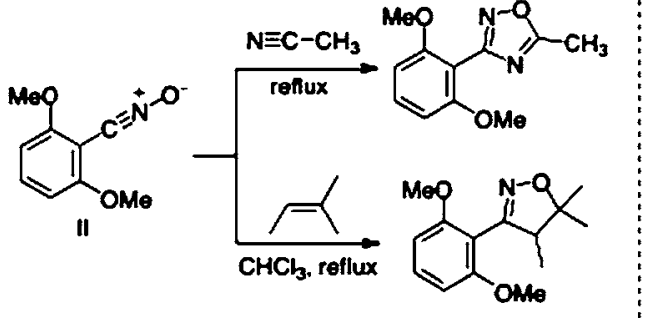

Figure 5 Model reaction of stable nitrile $N$-oxide II with (b) 2-methyl-2-butene as dipolarophiles.

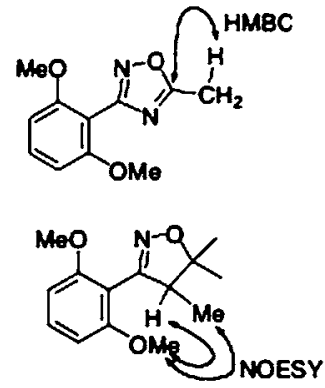

(a) acetonitrile and 
オレフインに対するそれぞれの付加率は，i） ${ }^{1} \mathrm{H}$ NMR中 の残存オレフィンとニトリルオキシド反応剤に由来するシ グナルの積分比と， ii） IR中のニトリル基 $\left(2238 \mathrm{~cm}^{-1}\right)$ とオレフィン由来の吸収帯 $\left(971 \mathrm{~cm}^{-1}\right)$ の吸光度の比を 反応前後で比較し，それらの連立式から算出した。その結 果，オレフィンに対しては $87 \%$ ，ニトリル基に対しては $48 \%$ の付加率で付加反応が進行したことが明らかとなった (Table 1, entry 1). また反応時間を 24 時間にしたところ， オレフィン，ニトリル基ともに定量的に付加反応が進行し たことが分かった（entry 2).2置換内部オレフィンとニ トリル基とでは，相対的にオレフィンの方が反応性が高い ことが示唆されたので，次に III当量を減らして付加反 応を検討した．オレフィンのモル当量と同量（0.67当量， entry 3）のIIを添加して 48 時間反応すると，オレフィ ン：78\%，ニトリル基：53\%の付加率であったが，IIの当 量を 0.33 当量まで減らすと（entry 4)，ほぼ選択的にオレ フィンのみへの付加が進行することが分かった。

この反応を基にして，次に他のニトリルオキシドを用い て付加反応を検討した（Figure 7）。ジエトキシ基を有す るニトリルオキシドIIIを用い, 同条件下で反応を行うと オレフィンに対しては $93 \% て ゙$ 付加したものの，ニトリル基 とは $37 \%$ と低い付加率であることが分かった（Table 2,

Table 1 Effect of feed ratio of $\mathbf{I I}$ and reaction time on modification reaction of $\mathrm{NBR}$

\begin{tabular}{|c|c|c|c|c|}
\hline entry & $\begin{array}{l}\text { nitrile } N \text {-oxide } \\
\text { (II) (equiv.) }\end{array}$ & $\begin{array}{l}\text { time } \\
\text { (h) }\end{array}$ & $\begin{array}{l}\text { product } \\
(\%)\end{array}$ & $\begin{array}{c}\text { conversion } \\
(\%)\end{array}$ \\
\hline \multirow[t]{2}{*}{1} & 1.2 & 2 & 99 & olefin: 87 \\
\hline & & & & CN: 48 \\
\hline \multirow[t]{2}{*}{2} & 1.2 & 24 & 99 & olefin: 99 \\
\hline & & & & CN: 99 \\
\hline \multirow[t]{2}{*}{3} & 0.67 & 48 & 90 & olefin: 78 \\
\hline & & & & CN: 53 \\
\hline \multirow[t]{2}{*}{4} & 0.33 & 48 & 99 & olefin: 43 \\
\hline & & & & CN: 5 \\
\hline
\end{tabular}

entry 1). またナフタレン骨格を持つニトリルオキシド IV を用いると, 立体的要因と電子要請の変化のため, オ レフィン，ニトリル基とも同程度の反応性を示し，それぞ れ 50\%程度の反応率となることが分かった (entry 2).

\section{$3.4{ }^{1} \mathrm{H}$ NMR およびIR測定による構造解析}

NBRに対してニトリルオキシドIIを付加して得られた ポリマー（Table 1, entry 2) の ${ }^{1} \mathrm{H}$ NMRスペクトルを示 す (Figure 8). II の付加によって，II由来の芳香族シグ ナル (a and b)，メトキシ基由来のシグナル (OMe) が 生成ポリマーのスペクトル（iii）に現れたことより，付加 反応が進行したことを確認した。 また，NBR（Figure 8， (ii)）の $5 \sim 6 \mathrm{ppm}$ 付近のオレフィン由来のシグナルが (iii）のスペクトル中で消失したことは，2重結合に対して 定量的に付加が進行したことを示している，一方，飽和炭 化水素領域のシグナルがブロード化しているのは, 生成ポ リマーが位置異性体及びジアステレオマーの混合物である ことに由来する構造的な不均一性や生成ポリマーの側鎖間 の立体的要因によって側鎖の運動がNMRのタイムスケー ル程度に遅くなったこと等に依存していると考えられる.

またニトリル基への付加率を確認すべく，IR 測定も行 った（Figure 9). 原料の NBRのスペクトル中（Figure 9,

Table 2 Effect of chemical structure of nitrile $N$-oxides on modification reaction of NBR.

\begin{tabular}{llcc}
\hline entry nitrile $N$-oxide (equiv.) & $\begin{array}{c}\text { time } \\
(\mathrm{h})\end{array}$ & $\begin{array}{c}\text { product } \\
(\%)\end{array}$ & $\begin{array}{c}\text { conversion } \\
(\%)\end{array}$ \\
\hline & & & \\
olefin: 93 \\
$\mathrm{CN}: 37$
\end{tabular}

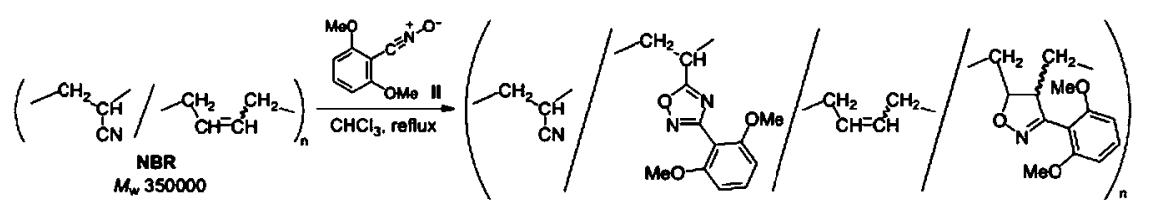

Figure 6 Modification of NBR using nitrile $N$-oxide $\mathbf{I I}$.

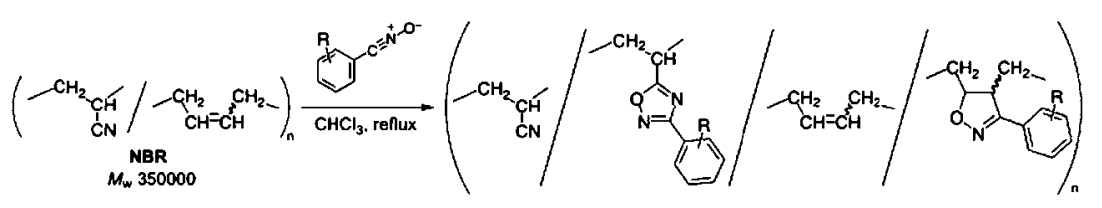

Figure 7 Modification of NBR using nitrile $N$-oxides III and IV. 


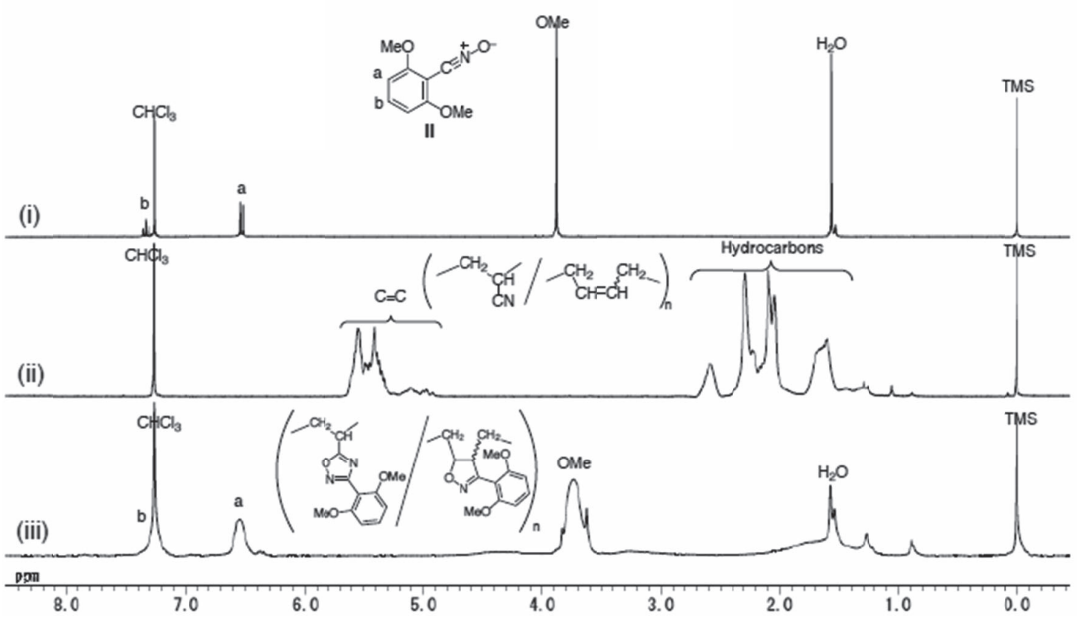

Figure $8{ }^{1} \mathrm{H}$ NMR spectra of (i) nitrile $N$-oxide II, (ii) virgin NBR, and (iii) functionalized NBR $\left(400 \mathrm{MHz}, \mathrm{CDCl}_{3}, 298 \mathrm{~K}\right)$.

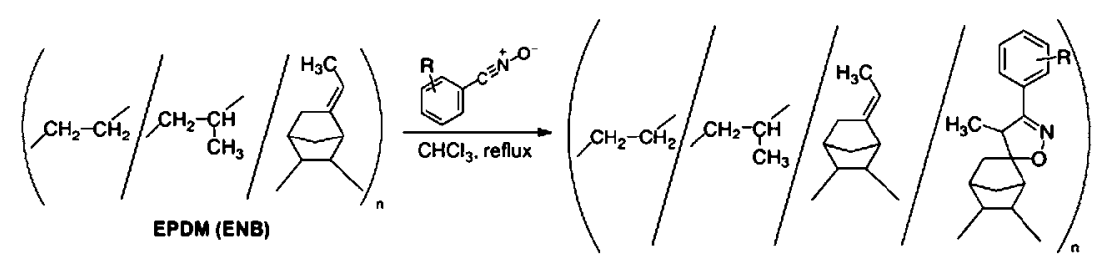

Figure 10 Modification of EPDM (ENB) using stable nitrile $N$-oxides.
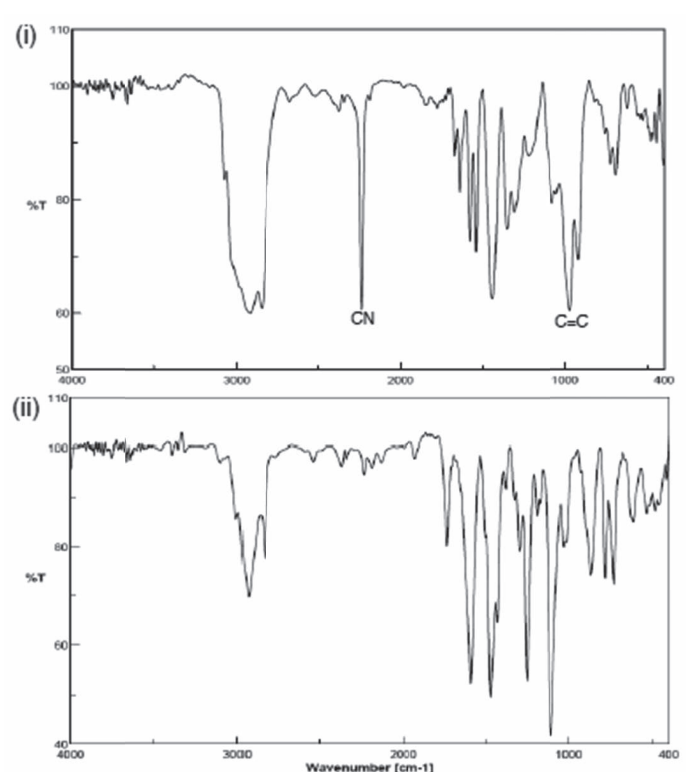

Figure 9 IR spectra of (i) virgin NBR and (ii) functionalized NBR $(\mathrm{KBr})$.
Table 3 Effect of chemical structure of nitrile $N$-oxides on modification reaction of EPDM (ENB)

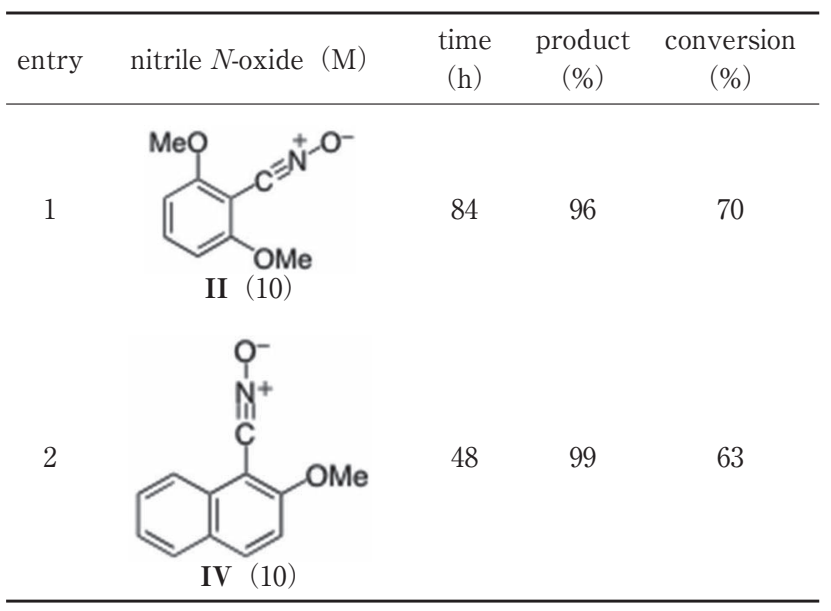

(i)）にあるニトリル基由来の $2200 \mathrm{~cm}^{-1}$ 付近の強いシグ ナルが生成ポリマーのスペクトル（ii）ではほとんど消失 していることょり，ニトリル基に対するIIの付加も定量 的に進行していることが明らかとなった。またオレフィン に由来する $960 \mathrm{~cm}^{-1}$ 付近の強いシグナルも完全に消失し ていることから，2重結合への付加反応が定量的に進行し ていることをIRからも再度確認した。

\subsection{EPDM（ENB）およびNRの修飾反応}

このように，内部オレフィンと無触媒で環化付加反応を 起こすことが明らかとなったため，次に 3 置換内部オレフ インを有している EPDM（ENB）と NRとの反応について
検討した (Figures 10 and 11).EPDM（ENB）を用いて 反応を行うと，NBRよりも反応速度は低下したものの， 基質濃度を高くすると（ニトリルオキシド濃度が $10 \mathrm{M}$ ) 問題なく反応が進行し，1.0当量の II を用いたときは 3.5 日 後には約 70\%の修飾率となった（Table 3, entry 1)。ま たIVを用いた際には，2 日後には $63 \%$ 修飾率となった (entry 2).

またNRに対しても，同様に修飾反応を検討した（Figure 11). EPDM (ENB) よりもさらにオレフィンの立体 障害が大きいため反応性は劣るものの，ニトリルオキシド を 2.0 当量混合すると, $56 \%$ の付加率で対応する修飾 NRが 得られた。この反応についての条件の最適化は行っていな いものの， 3 置換オレフィンに対する有効な高分子修飾反 応系であることが明らかとなった。

\section{6 固相状態での修飾反応}

1,3-双極子付加反応は Diels-Alder 反応と類似しており, 反応濃度が反応効率に大きく影響することがこれまでに知 られている，そこで次により効率的且つ実用的な反応条件

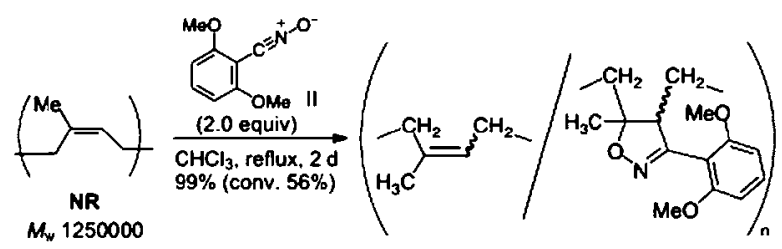

Figure 11 Modification of NR using stable nitrile $N$-oxide II. 

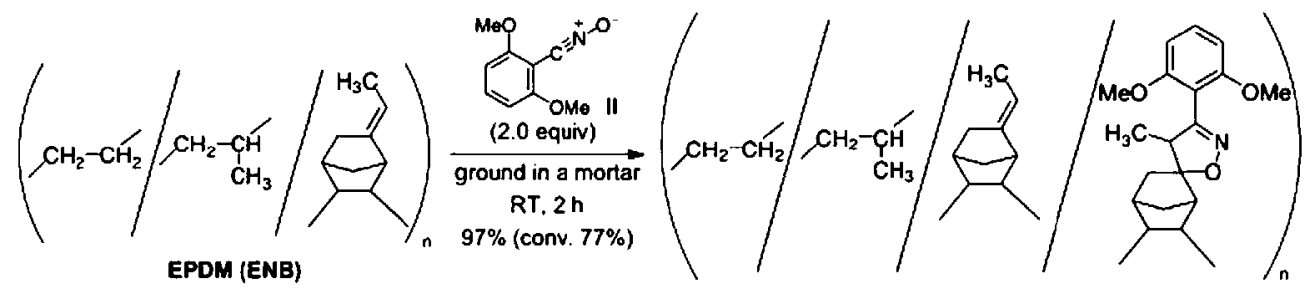

Figure 12 Solid state reaction for modification of EPDM (ENB).

として，無溶媒での混練りによる付加反応を検討した．固 相反応の初期的知見を得るために，EPDM（ENB）を凍 結粉砕器でパウダー状にし，そのパウダーをニトリルオキ シドと一緒に乳鉢上で加圧混合することで固相反応を実施 した（Figure 12）。乳鉢上でEPDMとニトリルオキシド IIを室温で 2 時間人力で加圧混合し，過剩のニトリルオキ シドをメタノールで洗浄した後，付加率を測定した？その 結果，期待通り反応は加速され，わずか 2 時間で付加率が 77\%に達することが明らかとなった。固相反応での著しい 反応の加速は反応効率の向上のみならず，実用性の高い方 法論を示唆していると考えられる．今後，こうした基礎的 な付加反応の知見を基にして，標的となる物性発現を意図 した新規安定ニトリルオキシドの創成が重要な課題になる と期待される ${ }^{19,20)}$.

\section{4. 結 論}

本研究では，速度論的に安定化したニトリルオキシドを 利用したエラストマーの高分子修飾法について検討した. このニトリルオキシドは高い反応性を有しながらも加熱条 件下でも安定に取り扱うことができ，従来までのニトリル オキシドではほとんど反応不活性であったニトリル基や内 部オレフィンへの付加反応が進行することが明らかとなっ た。さらに進めた固相付加反応系は，触媒・溶媒が不要で あり，副生成物も伴わないことからも，非常にエラストマ 一の修飾に適したシステムであると考えられ，本修飾法は 今後のエラストマーの高度な技術革新を支える重要なツー ルになると期待される.

\section{References}

1) For a selected review concerning chemical modifications of polydiene elastomers, see: Brosse, J. C.; Campistron, I.; Derouet, D.; Hamdaoui, A. E.; Houdayer, S.; Reyx, D.; Ritoit-Gillier, S.: J. Appl. Polym. Sci., 78, 1461 (2000)

2 ) Quillico, A.; Speroni, G.: Gazz. Chim. Ital., 76, 148 (1946)

3 ) Quillico, A.; Stagno d'Alcontres, G.; Grünanger, P.: Gazz. Chim. Ital., 80, 479 (1950)

4 ) Belen' Kii, L.: In “Nitrile Oxides, Nitrones, and Nitronates in Organic Synthesis (2nd ed.)", Feuer, H. Ed., Wiley, New York, p.1 (2006)

5 ) Barbaro, G.; Battalia, A.; Dondoni, A.: J. Chem. Soc. (B), 588 (1970)

6 ) Grundmann, C.; Kochs, P.: Angew. Chem., 82, 637 (1970)

7 ) Grundmann, C.; Kochs, P.; Boal, J. R.: Liebigs Ann. Chem., 761, $162(1972)$

8 ) Iwakura, Y.; Shiraishi, S.; Akiyama, M.; Yuyama, M.: Bull. Chem. Soc. Jpn., 41, 1648 (1968)

9 ) Iwakura, Y.; Uno, K.; Hong, S.-J.; Hongu, T.: Polym. J., 2, 36 (1971)

10) Hong, S. J.; Iwakura, Y.; Uno, K.: Polymer, 12, 521 (1971)

11) Kanbara, T.; Ishii, T.; Hasegawa, K.; Yamamoto, T.: Polym. Bull., 36, 673 (1996)

12) Koyama, Y.; Yonekawa, M.; Takata, T.: Chem. Lett., 37, 918 (2008)

13) Lee, Y.-G.; Koyama, Y.; Yonekawa, M.; Takata, T.: Macromolecules, 42, 7709 (2009)

14) Singh, I.; Zarafshani, Z.; Lutz, J.-F.; Heaney, F.: Macromolecules, 42, 5411 (2009)

15) Gutsmiedl, K.; Wirges, C. T.; Ehmke, V.; Carell, T.: Org. Lett., 11, 2405 (2009)

16) Grundmann, C.; Richter, R.: J. Org. Chem., 33, 476 (1968)

17) Beltrame, P.; Veglio, C.; Simonetta, M.: J. Chem. Soc. (B), 867 (1967)

18) Bode, J. W.; Hachisu, Y.; Matsuura, T.; Suzuki, K.: Tetrahedron Lett., 44, 3555 (2003)

19) Lee, Y.-G.; Yonekawa, M.; Koyama, Y.; Takata, T.: Chem. Lett., 39, $420(2010)$

20) Lee, Y.-G.; Koyama, Y.; Yonekawa, M.; Takata, T.: Macromolecules, 43, 4070 (2010) 